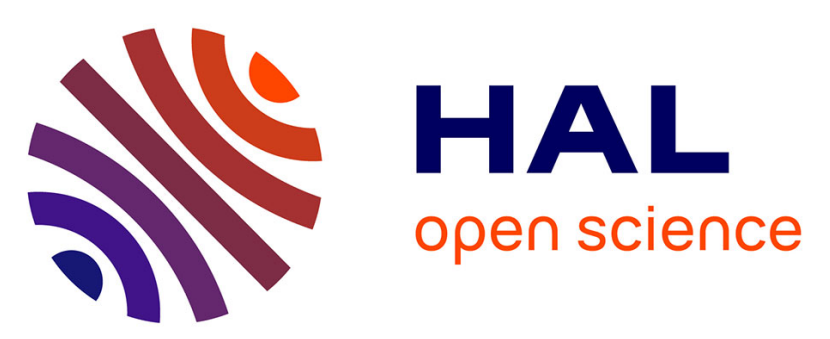

\title{
A scientific note on the detection of spores of Paenibacillus larvae in naturally and artificially contaminated honey: comparison of cultural and molecular methods
}

Stefano Bassi, Elena Carra, Emanuele Carpana, Gian Luca Paganelli, Stefano Pongolini

\section{To cite this version:}

Stefano Bassi, Elena Carra, Emanuele Carpana, Gian Luca Paganelli, Stefano Pongolini. A scientific note on the detection of spores of Paenibacillus larvae in naturally and artificially contaminated honey: comparison of cultural and molecular methods. Apidologie, 2010, 41 (4), 10.1051/apido/2009059 . hal-00892062

\section{HAL Id: hal-00892062 https://hal.science/hal-00892062}

Submitted on 1 Jan 2010

HAL is a multi-disciplinary open access archive for the deposit and dissemination of scientific research documents, whether they are published or not. The documents may come from teaching and research institutions in France or abroad, or from public or private research centers.
L'archive ouverte pluridisciplinaire HAL, est destinée au dépôt et à la diffusion de documents scientifiques de niveau recherche, publiés ou non, émanant des établissements d'enseignement et de recherche français ou étrangers, des laboratoires publics ou privés. 


\title{
A scientific note on the detection of spores of Paenibacillus larvae in naturally and artificially contaminated honey: comparison of cultural and molecular methods*
}

\author{
Stefano BAssi ${ }^{1}$, Elena CARra ${ }^{1}$, Emanuele CARPANA $^{2}$, Gian Luca PAGANElli ${ }^{1}$, Stefano PongolinI $^{1}$ \\ ${ }^{1}$ Istituto Zooprofilattico Sperimentale della Lombardia e dell'Emilia Romagna, Sezione di Modena Via E. Diena 16, \\ 41100 Modena, Italy \\ ${ }^{2}$ Consiglio per la Ricerca e la Sperimentazione in Agricoltura - Unità di ricerca di apicoltura e bachicoltura, \\ Via di Saliceto 80, 40128 Bologna, Italy
}

Received 7 April 2009 - Revised 31 July 2009 - Accepted 11 August 2009

Paenibacillus larvae / spore / honey / PCR / bacterial culture

The detection of Paenibacillus larvae spores in honey produced by infected colonies enables an early identification of American foulbrood (Ritter, 2003). Bacterial culture with colony counting is the reference method for $P$. larvae spores assessment in honey (OIE, 2008), but it is time consuming and the overgrowth of other Bacilli can confuse the results.

Kilwinski et al. (2004) developed a threereaction PCR protocol with high specificity towards $P$. larvae for accurate species identification. Given the specificity of that protocol, in our study we assessed the sensitivity of one of those reactions as a faster alternative to culture for the detection of $P$. larvae spores in honey samples. The reaction was chosen for its superior efficiency compared to the others (unpublished data).

The analytical sensitivity of both PCR and bacterial culture was determined. Then, PCR was compared to culture to determine its ability to discriminate non-contaminated from contaminated samples with different loads of spores.

One hundred and two samples were tested. They included 91 honeys from apicultural production, 4 artificially-contaminated honey samples containing approximately $10000,1000,100$ and 10 spores of $P$. larvae per gram, 1 spore-free honey, 6 water suspensions of $P$. larvae spores ranging from $10^{4}$ to $10^{-1}$ spores $/ \mathrm{mL}$. The spores for water suspensions and artificially-contaminated honeys were

Corresponding author: S. Pongolini,

stefano.pongolini@izsler.it

* Manuscript editor: David Tarpy harvested from dead larvae and counted in a Bürker chamber.

Samples were pre-treated for culture and PCR as follows: five grams of each honey sample were diluted with $5 \mathrm{~mL}$ of sterile distilled water by vigorous shaking (obtaining a final volume of $8.8 \mathrm{~mL}$ ) and centrifuged at $3500 \times g$ for $45 \mathrm{~min}$. The supernatant was eliminated leaving $2 \mathrm{~mL}$ in the tube and the pellet was re-suspended in this volume by vigorous shaking for $1 \mathrm{~min}$. The re-suspended sample was heated at $85-90{ }^{\circ} \mathrm{C}$ for $15 \mathrm{~min}$ in a water bath (Alippi et al., 2004). Water suspensions were subjected to heat treatment without previous dilution and centrifugation. Artificially-contaminated honeys were diluted with $5 \mathrm{~mL}$ of sterile distilled water (obtaining a final volume of $8.8 \mathrm{~mL}$ ) and subjected to heat treatment without previous centrifugation.

\section{Cultural method}

Four hundred microliters of each pre-treated sample were plated onto 4 plates $(100 \mu \mathrm{L} /$ plate $)$ of MYPGP agar (Dingmann and Stahly, 1983), with $3 \mathrm{mg} / \mathrm{L}$ of nalidixid acid (Hornitzky and Clark, 1991). The plates were incubated at $37^{\circ} \mathrm{C}$ in $10 \%$ $\mathrm{CO}_{2}$ and examined after 3 and 8 days. Five suspected colonies per plate were tested for catalase reaction. Catalase-negative colonies were Gram stained and Gram-positive rods were directly submitted to PCR for species confirmation (DNA was extracted by heat treatment).

\section{$\underline{P C R}$}

Following pre-treatment, the samples $(1.5 \mathrm{~mL}$ for honeys, $4 \mathrm{~mL}$ for water suspensions, $8 \mathrm{~mL}$ for 
Table I. Evaluation of the analytical sensitivity for artificially-contaminated samples.

\begin{tabular}{lcc}
\hline \multicolumn{2}{c}{ Artificially-contaminated honey samples } \\
\hline \multirow{2}{*}{ Added spores /g } & \multicolumn{2}{c}{ Result } \\
\cline { 2 - 3 } & PCR & Culture (CFU/g)* \\
\hline 10000 & Pos. & Pos. (188) \\
1000 & Pos. & Pos. (33) \\
100 & Pos. & Pos. (8) \\
10 & Neg. & Neg. \\
0 & Neg. & Neg. \\
\hline
\end{tabular}

\begin{tabular}{ccc}
\hline \multicolumn{3}{c}{ Water suspensions } \\
\hline \multirow{2}{*}{ Added spores $/ \mathrm{mL}$} & \multicolumn{2}{c}{ Result } \\
\cline { 2 - 3 } & PCR & Culture (CFU/mL)* \\
\hline 10000 & Pos. & Pos. (293) \\
1000 & Pos. & Pos. (76) \\
100 & Pos. & Pos. (6) \\
10 & Pos. & Neg. \\
1 & Neg. & Neg. \\
0.1 & Neg. & Neg. \\
\hline
\end{tabular}

* In brackets the mean (rounded up) of two independent experiments performed in triplicate $(N=6$ for each level of contamination).

artificially-contaminated honeys) were centrifuged at $3500 \times g$ for $45 \mathrm{~min}$ and the pellet re-suspended with $200 \mu \mathrm{L}$ of Lysozyme solution followed by proteinase $\mathrm{K}$ treatment as previously reported (Bakonyi et al., 2003). DNA was purified by NucleoSpin tissue minikit (Macherey - Nagel) and eluted in $100 \mu \mathrm{L}$ of elution buffer. PCR was performed in a reaction volume of $25 \mu \mathrm{L}$ (with $5 \mu \mathrm{L}$ of template DNA), according to Fast Start Taq kit (Roche), with $0.5 \mu \mathrm{M}$ of primers PLL-16S F6 and PLL-16S B11 (Kilwinski et al., 2004).

The amplification protocol comprised $5 \mathrm{~min}$ at $95^{\circ} \mathrm{C}$, followed by 40 cycles at $94^{\circ} \mathrm{C}$ for $30 \mathrm{~s}, 56^{\circ} \mathrm{C}$ for $30 \mathrm{~s}, 72{ }^{\circ} \mathrm{C}$ for $45 \mathrm{~s}$, and a final extension at $72{ }^{\circ} \mathrm{C}$ for $7 \mathrm{~min}$.

Ten microliters of amplification product were electrophoresed on $1.8 \%$ agarose gel followed by staining in ethidium bromide $(1 \mu \mathrm{g} / \mathrm{mL})$ and visualization by UV transillumination.

Analytical sensitivity was determined in two separate experiments carried out in triplicate. Results are summarised in Table I.

In artificially-contaminated honeys the limit level of 100 spores/g was detected by culture and PCR. At this level of contamination, culture revealed $8 \mathrm{CFU} / \mathrm{g}$. Lauro et al. (2003) reported a similar sensitivity $(9 \mathrm{CFU} / \mathrm{mL})$ with a nested PCR preceded by an incubation step in MYPGP broth. Conversely, our protocol is based on a direct PCR with a reduced probability of false-positives and without pre-incubation, to increase simplicity.

In water suspensions of spores the detection limit of the cultural method was 100 spores $/ \mathrm{mL}$, while PCR was able to detect 10 spore $/ \mathrm{mL}$, corresponding to the template DNA from 2 spores per reaction. This difference was probably due to the limited germination capacity of spores on culture media (Nordström and Fries, 1995). In this study we observed germination rates between $1.9 \%$ and $8 \%$ in artificially-contaminated honeys and between $2.9 \%$ and $7.6 \%$ in water suspensions. These results are consistent with those of Forsgren et al. (2008). The superior sensitivity of PCR for water suspensions compared to honeys could be due to PCR inhibitors or less effective DNA extraction from honey. Piccini et al. (2002) have already reported strong PCR inhibition by honey. These authors needed $10^{-1}$ dilution of the DNA extracted by a simple microwave treatment to have amplification, obtaining a sensitivity of $170 \mathrm{CFU} / \mathrm{mL}$. The extraction procedure that we used significantly reduced inhibition with only $1 \log$ difference in sensitivity between water suspensions and honeys, without DNA dilution.

Among the naturally-occurring honey samples, 34 were PCR and culture positive, 28 were PCR and culture negative, 15 were PCR positive and culture negative and 14 were PCR negative and culture positive. Culture positive samples ranged from 1 to $1460 \mathrm{CFU} / \mathrm{g}$. Among them, the 14 PCR-negative samples had low CFU/g counts (between 1 and 7).

In conclusion, these results indicate that the PCR protocol employed is as sensitive as culture with MYPGP for $P$. larvae spores detection in honey, but it gives results in 24 hours instead of 8 days. Furthermore, the combination of DNA extraction and amplification protocol that we propose is simpler and less prone to false-positives than the previously proposed nested PCR by Lauro et al. (2003).

\section{ACKNOWLEDGEMENTS}

The Authors wish to thank Mr Vanni Righetti and Mrs Roberta Giannasi for technical assistance. 
Note scientifique sur la recherche de spores de Paenibacillus larvae dans des échantillons de miel naturellement et artificiellement contaminés : comparaison entre méthodes culturales et moléculaires.

Eine wissenschaftliche Notiz über den Nachweis von Sporen von Paenibacillus larvae in natürlich und künstlich kontaminierten Honigproben: Ein Vergleich von Kultivierungs- und molekularen Methoden.

\section{REFERENCES}

Alippi A.M., Reynaldi F.J., López A.C., De Giusti M.R., Aguilar O.M. (2004) Molecular epidemiology of Paenibacillus larvae larvae and incidence of American foulbrood in Argentinian honeys from Buenos Aires province, J. Apic. Res. 43, 135-143.

Bakonyi T., Derakhshifar I., Grabensteiner E., Nowotney N. (2003) Development and evaluation of PCR assays for the detection of Paenibacillus larvae in honey samples: comparison with isolation and biochemical characterization, Appl. Environ. Microbiol. 69, 1504-1510.

Dingmann D.W., Stahly D.P. (1983) Medium promoting sporulation of Bacillus larvae and metabolism of medium components, Appl. Environ. Microbiol. 46, 860-869.
Forsgren E., Stevanovic J., Fries I. (2008) Variability in germination and in temperature and storage resistance among Paenibacillus larvae genotypes, Vet. Microbiol. 129, 342-349.

Hornitzky M.A.Z., Clark S. (1991) Culture of Bacillus larvae from bulk honey samples for the detection of American foulbrood, J. Apic. Res. 30, 13-16.

Kilwinski J., Peters M., Ashiralieva A., Genersch E. (2004) Proposal to reclassify Paenibacillus larvae subsp. pulvifaciens DSM 3615 (ATCC 49843) as Paenibacillus larvae subsp. larvae. Results of a comparative biochemical and genetic study, Vet. Microbiol. 104, 31-42.

Lauro F.M., Favaretto M., Covolo L., Rassu M., Bertoloni G. (2003) Rapid detection of Paenibacillus larvae from honey and hive samples with a novel nested PCR protocol, Int. J. Food Microbiol. 81, 195-201.

Nordström S., Fries I. (1995) A comparison of media and cultural conditions for identification of Bacillus larvae in honey, J. Apic. Res. 34, 97-103.

OIE (2008) Manual of Diagnostic Tests and Vaccines for Terrestrial Animals, Chap. 2.2.2, pp. 395-404. http:// www.oie.int/eng/normes/mmanual/2008/pdf/2.02.02_ AMERICAN_FOULBROOD.pdf

Piccini C., D’Alessandro B., Antúnez K., Zunino P. (2002) Detection of Paenibacillus larvae subspecies larvae spores in naturally infected bee larvae and artificially contaminated honey by PCR, World J. Microbiol. Biotechnol. 18, 761-765.

Ritter W. (2003) Early detection of American foulbrood by honey and wax analysis, Apiacta 38, 125-130. 